\title{
HUBUNGAN ANTARA KESEMPATAN BERMAIN, KEBUGARAN TUBUH, DAN KEMAMPUAN MENGGUNAKAN MEDIA BALOK DENGAN PERKEMBANGAN MOTORIK ANAK PADA TAMAN KANAK KANAK DI KOTA MEDAN
}

\author{
Erna Kusnita \\ Kepala TK ABA Bromo Medan \\ Email: dra.ernakusnita@yahoo.co.id
}

\begin{abstract}
Abstrak
Tujuan penelitian ini adalah untuk mengetahui : 1) hubungan positif yang berarti antara kesempatan bermain dengan perkembangan motorik anak TK, 2) hubungan positif yang berarti antara kebugaran tubuh dengan perkembangan motorik anak TK, 3) hubungan positif yang berarti antara kemampuan menggunakan media balok dengan perkembangan motorik anak TK, 4) hubungan positif yang berarti antara kesempatan bermain, kebugaran tubuh, dan kemampuan menggunakan media balok secara bersama - sama dengan perkembangan motorik anak TK. Penelitian dilakukan terhadap murid TK di Kota Medan yang berjumlah 12.973 orang. Penetapan sampel dilakukan dengan menggunakan rumus Yamane sehingga sample diperoleh sebanyak 100 orang yang terdiri dari 5 unit TK. Data dikumpulkan dengan menggunakan tes, angket, dan daftar isian. Data dianalisis dengan teknik analisis deskriptif dan infrensial korelasi. Hasil penelitian menunjukkan bahwa: 1) terdapat hubungan positif yang signifikan antara kesempatan bermain dengan perkembangan motorik anak dengan kontribusi sebesar $29 \%, 2$ ) terdapat hubungan positif yang signifikan antara kebugaran tubuh dengan perkembangan motorik anak dengan kontribusi sebesar $47.7 \%, 3$ ) terdapat hubungan positif yang signifikan antara kesempatan bermain, kebugaran tubuh, dan kemampuan menggunakan media balok secara bersama - sama sebesar $37.58 \%$.
\end{abstract}

Kata kunci : bermain, kebugaran tubuh, media balok dan motorik

\section{PENDAHULUAN}

Dewasa ini, pengembangan dan pembinaan potensi anak usia dini memperoleh perhatian yang banyak dan serius dari sejumlah pihak, khususnya pemerintah. Semua menyadari anak usia dinilah yang menjadi penerus generasi di masa akan datang. Untuk itu, perlu pembinaan dan pengembangan yang sesuai dengan karakteristik dan kebutuhan anak. Dari sisi perkembangan anak, masa usia dini dikenal dengan masa emas perkembangan (golden age). Masa itu sebagai suatu masa terjadinya perkembangan yang pesat pada diri anak. Potensi yang dimiliki anak berpeluang besar untuk berkembang optimal.

Pemahaman tentang pentingnya masa usia dini bagi manusia berdampak terhadap kebijakan pemerintah saat ini. Dalam dunia internasional, keseriusan pemerintah direalisasi dengan mengikatkan diri dalam The World Education forum pada Deklarasi Dakkar di Senegal tahun 2000 yang menghasilkan program Education for 
All (EFA) yang dilanjutkan dengan komitmen World Fit for Children, New York 8 Mei 2002. Kebijakan di dalam negeri ditunjukkan dengan lahirnya Undang-Undang Republik Indonesia Nomor 23 Tahun 2002 tentang Perlindungan Anak. Keseriusan tersebut juga ditegaskan dengan keberadaan Pasal 28 UndangUndang Republik Indonesia Nomor 20 Tahun 2003 tentang Sistem Pendidikan Nasional dan munculnya Direktorat Pendidikan Anak Usia Dini dalam pemerintahan. Kebijakan tersebut menempatkan Pendidikan Anak Usia Dini dalam tatanan pemerintahan dan kehidupan masyarakat dengan kekuatan hukum yang jelas.

Pendidikan Anak Usia Dini
dapat diselenggarakan dalam
berbagai bentuk. Salah satu di
antaranya adalah dalam bentuk
Taman Kanak-Kanak (TK). TK
bertugas melakukan upaya
pembinaan melalui rangsangan
pendidikan. Rangsangan tersebut
dilaksanakan dengan cara bermain
sambil belajar dan belajar seraya
bermain dengan nuansa
pembelajaran aktif, efektif, kreatif,
dan menyenangkan. Dalam
pembelajaran di TK bidang
pengembangan pembiasaan sikap
dan moral agama dikembangkan
dengan kegiatan rutinitas dan
terprogram sedangkan
pengembangan kemampuan dasar
bahasa, kognitif, fisik motorik dan
seni dikemas secara terpadu dan
terintegrasi dalam pembelajaran di
TK. Lingkungan belajar ditata sesuai

dengan tema yang sedang dibahas dan disusun oleh guru. Dengan lingkungan belajar yang kondusif dan menyenangkan serta nyaman akan menunjang proses pembelajaran di TK.

Kesiapan anak dapat dilihat dari berbagai aspek perkembangan. Kurikulum TK yang berlaku sekarang, yaitu Kurikulum Berbasis Kompetensi Tahun 2004 menetapkan ada enam aspek perkembangan anak, yaitu fisik dan motorik, bahasa, kognitif, sosial emosional, seni, serta nilai dan moral agama. Hurlock (1996) mengemukakan bahwa perkembangan motorik merupakan salah satu faktor yang sangat penting dalam perkembangan individu secara keseluruhan. Sejalan dengan Hurlock, Collins dalam Sumantri (2005) menegaskan bahwa perkembangan motorik erat kaitannya dengan perkembangan berpikir dan kecerdasan. Selanjutnya ia menjelaskan bahwa perkembangan motorik merupakan berfungsinya anggota gerak tubuh. Berdasarkan kedua pendapat tersebut dapat dinyatakan bahwa perkembangan motorik mempengaruhi perkembangan aspek-aspek yang lain. Ini berarti, perkembangan motorik sangat penting dalam cakupan perkembangan diri anak secara keseluruhan. Dengan demikian aspek perkembangan motorik perlu memperoleh perhatian yang besar dalam rangka perkembangan diri yang optimal.

Hasil observasi Anita (2006) pada anak kelas V Sekolah Dasar 
(SD) menunjukkan bahwa adanya keluhan tentang kualitas tulisan anak. Tulisan anak sering kali memerlukan tenaga dan waktu yang banyak untuk memahaminya. Belum kelihatan perbedaan yang jelas antara tulisan huruf 'a' dan 'o' dalam satu kata, di antaranya tulisan 'pagar' sering kali ditulis seperti 'pogor', 'kelapa' jadi 'kelopo'. Arah tulisan belum konsisten. Ada tulisan satu kata yang miring ke kanan dan yang satu lagi miring ke kiri, ukuran besar huruf dalam satu kata juga belum seimbang ukurannya. Misalnya huruf 's' dalam kata 'pasang' kelihatan besar sekali dibanding huruf ' $\mathrm{p}, \mathrm{a}, \mathrm{a}, \mathrm{n}$, dan g' sehingga menjadi seperti [paSang]. Akibatnya, tulisan anak sukar dibaca dan orang lain sukar memahami apa yang ditulis anak. Menurut Puckett dan Diffily (2004) pada usia kelas V SD seharusnya anak sudah bisa menuliskan kata dengan ukuran yang seimbang dan jelas bentuknya sehingga mudah dibaca.

Puckett dan Diffily (2004) menyatakan bahwa kesulitan anak menulis dengan baik dan benar antara lain disebabkan oleh perkembangan motorik yang belum matang. Perkembangan motorik khusus motorik halus yang berkaitan dengan menulis belum berkembang maksimal. Jari-jari tangan yang digunakan untuk menulis belum dapat bergerak luwes dan lentur. Akibatnya, saat menulis anak kesulitan memegang dan menggerakkan alat tulis. Aspek yang lain yang diperkirakan mempengaruhi aktivitas menulis adalah kordinasi mata dan tangan yang belum terjalin baik. Kedua hal itu termasuk menjadi bagian dari perkembangan motorik.

Hasil pengamatan peneliti menunjukkan bahwa aktifitas pengembangan motorik anak TK kurang mendapat prioritas oleh guru disebabkan kurang pahamnya guru tentang perkembangan motorik anak. Dalam kegiatan pembelajaran di TK guru selalu mengutamakan kegiatan pengembangan kognitif, sedangkan kegiatan pengembangan motorik hanya pada saat anak bermain bebas.

Berdasarkan uraian yang telah dikemukakan, dapat dinyatakan bahwa perkembangan motorik berkaitan dengan kegiatan akademik anak kelak di sekolah lanjutan. Bila hal tersebut diabaikan diperkirakan anak akan mengalami kesulitan dalam melakukan kegiatan akademik, seperti menulis.

Mutohir

mengemukakan bahwa

perkembangan aspek motorik dipengaruhi oleh aspek fisik, yaitu kesegaran jasmani atau kebugaran tubuh (physical fitness). Kesegaran jasmani menurut Getchell (1983) sebagai kebugaran tubuh yang menunjukkan suatu kemampuan yang menitikberatkan pada fungsifungsi biologis. Lebih lanjut Getchell (1983) menjelaskan bahwa fungsi aspek biologis dapat dilihat dari pertumbuhan fisik yang seimbang seperti ukuran tubuh, kaki, tangan dan kepala. Ketiga aspek dimiliki anak bervariasi. 
Menurut Moore (2005) media menjadi salah satu komponen utama dalam kegiatan belajar untuk anak usia dini. Banyak media yang dapat digunakan untuk belajar dan bermain, salah satu media yang selalu disediakan TK adalah balok. Hal ini dipertegas oleh Chalufour dan Woth (2004) bahwa salah satu media yang dapat digunakan dan membuat anak senang belajar dan bermain adalah media balok. Media balok memberi sumbangan yang berarti bagi perkembangan motorik anak. Anak yang mampu menggunakan balok dalam berbagai kegiatan belajar akan mendukung perkembangan motorik yang maksimal. Aktivitas anak dengan balok antara lain dengan cara memegang, menyusun, dan memasang-masangkan balok sehingga menjadi suatu bentuk yang bervariasi. Semakin variasi jumlah, bentuk dan susunan yang dihasilkan anak dengan balok menggambarkan kemampuan yang baik dalam penggunaan balok.

$$
\text { Adapun yang menjadi }
$$
identifikasi masalah pada penelitian ini adalah: (1) perkembangan motorik anak yang masih sangat rendah, (2) pertumbuhan anak TK selama ini masih belum baik, (3) guru belum mampu memacu peningkatan perkembangan motorik anak, (4) Aktifitas yang dilakukan oleh guru dalam belajar belum merangsang perkembangan motorik anak.

Disadari banyak hal yang mempengaruhi perkembangan motorik anak TK. Untuk memperoleh bahasan yang mendalam dan rinci, peneliti membatasi permasalahan pada perkembangan motorik anak, kesempatan bermain, kebugaran tubuh, dan kemampuan menggunakan media balok.

Berdasarkan identifikasi dan pembatasan masalah yang telah dikemukakan, maka rumusan masalah penelitian adalah :

a. Apakah terdapat hubungan positif dan berarti antara kesempatan bermain dengan perkembangan motorik anak TK di Kota Medan?

b. Apakah terdapat hubungan positif dan berarti antara kebugaran tubuh dengan perkembangan motorik anak TK di Kota Medan?

c. Apakah terdapat hubungan positif dan berarti antara kemampuan menggunakan media balok dengan perkembangan motorik anak TK di Kota Medan?

d. Apakah terdapat hubungan positif dan berarti antara kesempatan bermain, kebugaran tubuh dan kemampuan menggunakan media secara bersama - sama dengan perkembangan motorik anak TK di Kota Medan?

Secara umum penelitian ini bertujuan untuk mengetahui perkembangan motorik anak TK di Kota Medan kaitannya dengan aspek kesempatan bermain, kebugaran tubuh, dan kemampuan menggunakan media balok. Secara 
khusus penelitian ini bertujuan untuk mengetahui : (1) Hubungan positif kesempatan bermain dengan perkembangan motorik anak TK di Kota Medan, (2) Hubungan positif kebugaran tubuh dengan perkembangan motorik anak TK di Kota Medan, (3) Hubungan positif kemampuan menggunakan media balok dengan perkembangan motorik anak TK di Kota Medan, (4) Hubungan positif antara kesempatan bermain, kebugaran tubuh, dan kemampuan menggunakan media balok secara bersama - sama dengan perkembangan motorik anak TK.di Kota Medan.

$\begin{array}{ccc}\text { Hasil } & \text { penelitian yang } \\ \text { diperoleh } & \text { diharapkan dapat }\end{array}$
bermanfaat bagi peningkatan perkembangan motorik anak baik secara teoretis maupun secara praktis. Secara teoretis diharapkan dapat menambah khasanah ilmu pengetahuan khususnya tentang teori - teori yang berkaitan dengan perkembangan motorik dan hubungannya dengan kesempatan bermain, kebugaran tubuh dan kemampuan menggunakan media balok, dan juga sebagai acuan bagi peneliti yang lain yang mau meningkatkan pengembangan motorik anak. Secara praktis dapat memberikan informasi dalam mengambil kebijakan untuk pengembangan motorik anak TK.

Secara praktis hasil penelitian ini diharapkan bermanfaat bagi orang tua, guru TK, kepala TK, Diknas dan LPTK. Bagi orang tua, diharapkan hasil penelitian ini dapat membantu orang tua untuk mengenali perkembangan motorik anak serta menentukan kesempatan dan upaya untuk mengembangkan motorik anak. Bagi guru, diharapkan dapat digunakan untuk menyusun program dan kegiatan belajar yang dapat membantu anak untuk memaksimalkan perkembangan motorik anak. bagi Kepala TK dan TK, diharapkan memberi kesempatan dan mendorong guru untuk memaksimal program pengembangan motorik serta menyedaikan berbagai fasilitas (APE) yang berkaitan dengan perkembangan motorik. Bagi Diknas dan pemerintah, diharapkan mendukung program pengembangan motorik dengan menyediakan berbagai fasilitas yang mendukung perkembangan motorik. Bagi LPTK, diharapkan dapat membantu guru dalam mengembangkan program yang berkaitan dengan perkembangan motorik dan menyiapkan mahasiswa PAUD memiliki kompetensi melaksanakan kegiatan pengembangan motorik.

\section{TINJAUAN TEORI}

Hakikat Perkembangan Motorik AnakKarakteristik Taman Kanakkanak dan Anak Taman Kanakkanak

Membahas perkembangan motorik anak TK dimulai dengan melihat definisi TK dan anak TK. Nama TK (Kindergarten) menurut Feeney, Christensen dan Moravcik (2006) pertama kali dikemukakan oleh Froebel, yaitu dengan kata kinder ("child") yang berarti anak 
dan garten ("garden") yang berarti kebun sehingga keseluruhan berarti kebun untuk anak (garden for child.) Sedang Brewer (2007) mengemukakan bahwa TK sebagai suatu sekolah yang diselenggarakan sesuai dengan karakteristik dan kebutuhan anak dari usia empat tahun sampai usia enam tahun. Kedua batasan tersebut menunjukkan bahwa TK sebagai suatu lembaga, yaitu sekolah dan di dalamnya terdapat anak-anak yang mengikuti kegiatan sekolah, yaitu anak yang berusia empat sampai enam tahun.

Seefeldt dan Barbour (1994) mengemukakan bahwa kindergarten adalah tempat berlangsungnya kegiatan belajar melalui berbagai permainan untuk anak usia empat sampai lima tahun. Dengan demikian dapat dinyatakan bahwa anak TK adalah anak yang berusia antara usia empat tahun sampai lima tahun. Selanjutnya Brewer (2007) menjelaskan bahwa di beberapa negara anak yang sudah berusia lima tahun wajib dimasukkan ke dalam TK. Penjelasan tersebut memberi gambaran bahwa anak usia lima tahun memperoleh penekanan khusus, yaitu harus segera dimasukkan ke TK.

Perkembangan motorik anak TK yang menjadi fokus bahasan dalam penelitian ini adalah anak TK yang berusia lima tahunan (5 sampai 6 tahun). Alasan yang digunakan adalah pertama, penjelasan Brewer tentang anak usia lima tahun dapat mengikuti kegiatan di TK. Kedua, pendapat Dewantara (1977) yang menyebutkan Taman Anak dengan nama Taman Indria diperuntukkan bagi anak usia di bawah tujuh tahun. Kedua pendapat tersebut menggambarkan bahwa usia tertinggi anak TK adalah enam tahun. Berarti, pada saat memasuki TK, anak umumnya berusia lima tahun.

Sujiono, dkk mengidentifikasi perkembangan motorik dengan cara mengidentifikasi perkembangan dan motorik. Perkembangan menurut Sumantri (2005) merupakan proses perubahan kapasitas fungsional atau kemampuan kerja organ-organ tubuh ke arah keadaan yang makin terorganisasi dan terspesialisasi. Makin terorganisasi berarti organorgan tubuh makin bisa dikendalikan. Makin terspesialisasi artinya organ-organ tubuh makin bisa berfungsi sesuai dengan fungsi masing-masing. Motorik adalah semua gerakan yang didapat dari semua anggota tubuh. Berdasarkan uraian tersebut, Sujiono, dkk (2005) menyatakan bahwa perkembangan motorik sebagai pertambahan gerakan sehingga menjadi matang dan terkendali. Samsudin (2008) mengemukakan bahwa perkembangan motorik sebagai suatu penguasaan pola dan variasi gerak yang telah bisa dilakukan anak. Dua pendapat tersebut menekankan bahwa perkembangan motorik sebagai gerakan yang memiliki pola dan variasi.

Feeney, Christensen dan Moravcik (2006) mengemukakan perkembangan motorik anak dibagi 
tiga tahap, yaitu infant, toddler dan preschool. Mereka lebih

\section{Hakikat Kesempatan Bermain}

Bermain menurut Santoso (2002) adalah suatu kegiatan atau tingkah laku yang dilakukan anak secara sendirian atau berkelompok dengan menggunakan alat atau tanpa alat untuk mencapai tujuan tertentu. Pada hakikatnya bermain ada yang dapat dilakukan secara sendiri dan adapula yang dapat dilakukan secara kelompok.

Bermain di TK merupakan suatu kegiatan yang dilakukan secara berulang - ulang dan menimbulkan kesenangan atau kepuasan bagi seseorang. Upaya melalui bermain memberi kepuasan kepada anak untuk bereksplorasi, menemukan, mengekspresikan perasaan, berkreasi, dan belajar secara menyenangkan. Selain itu bermain membantu anak mengenal dirinya sendiri, dengan siapa ia hidup, serta lingkungan tempat ia hidup. Jadi bermain memberikan kontribusi khusus pada semua aspek perkembangan anak, terutama perkembangan motorik, sehingga kegiatan yang dilakukan anak dilakukannya melalui aktivitas bermain.

Menurut Sujiono, dkk (2009) fungsi bermain dapat menunjang perkembangan motorik, bahasa, sosial, kecerdasan emosi, kreativitas, bahkan bermain dapat dijadikan suatu terapi. Ternyata bermain memegang fungsi yang penting dalam perkembangan anak.
Monks dkk

menyebutkan bahwa secara khusus permainan dapat berfungsi sebagai penyaluran bagi manusia untuk melepaskan sisa - sisa energi. Sue dockett (1999) menyatakan bahwa permainan memiliki tiga fungsi, yaitu permainan yang mengarah pada penemuan, penalaran, dan pemikiran.

Parten dalam Mayke (2001) mengemukakan bermain dari aspek sosial. Menurutnya bermain memiliki tahapan yang terdiri dari bermain solitaire, yaitu anak bermain sendiri, onlooker, yaitu perkembangan bermain yang menunjukkan anak sebagai pengamat, bermain parallel, yaitu anak bermain berdampingan, tapi belum berkomunikasi, bermain associative, yaitu anak sudah bisa bermain bersama, tetapi belum bekerja sama, dan terakhir bermain cooperative, yaitu anak sudah bisa bermain dengan bekerja sama.

Setiap anak pada usia yang berbeda mempunyai tahapan bermain yang berbeda pula. Hal ini juga menjadi dasar pemilihan jenis dan konsep permainan yang akan diterapkan. Apabila jenis dan konsep bermain tidak disesuaikan dengan tahapan bermain anak, maka tujuan bermain anak tidak akan tercapai. Oleh karena itu pendidik harus memahami tahapan perkembangan bermain anak yang akan melakukan kegiatan bermain.

\section{Hakikat Kebugaran Tubuh}

Pengertian kebugaran tubuh beraneka ragam dan tergantung dari sudut pandang seseorang mengkaji 
kebugaran tubuh. Kebugaran tubuh lebih sering disebut kesegaran jasmani. Kalau ditinjau dari segi etimologis, kata kesegaran jasmani berasal dari kata " fit " yang artinya sehat. Seseorang dalam keadaan kondisi fit, maka ia mempunyai kondisi badan yang sehat untuk mempertahankan diri dari pengaruh pengaruh luar tubuh. Hal ini berarti seseorang sanggup melawan pengaruh - pengaruh luar dan tidak mengurangi efisiensi kondisi badan serta keharmonisan proses organisme dalam tubuh.

Getchell

mendefinisikan kesegaran jasmani atau kebugaran tubuh adalah suatu kemampuan yang menitikberatkan pada fungsi-fungsi fisiologis, yaitu kemampuan jantung, pembuluh darah, paru-paru, dan otot berfungsi pada efisiensi yang optimal. Fox (1986) menyatakan kesegaran jasmani adalah suatu kapasitas fisiologis atau fungsional yang memberikan suatu kualitas hidup yang meningkat. Selanjutnya O Sullivan (1987) menyatakan kesegaran jasmani adalah suatu kemampuan untuk melakukan kegiatan sehari - hari yang normal dengan giat dan penuh kesiapsiagaan, tanpa mengalami kelelahan yang berarti dan masih mempunyai cadangan energi untuk menikmati kegiatan waktu senggang serta kejadian darurat yang datang tiba - tiba. Kemudian kesegaran jasmani adalah kecocokan keadaan fisik terhadap tugas yang harus dilaksanakan oleh fisik itu untuk dapat melaksanakan tugas tertentu dengan hasil yang baik. Di tegaskan oleh Sutarman (1975) Kesegaran jasmani adalah suatu aspek fisik dari kesegaran menyeluruh (total fitness) yang memberi kesanggupan kepada seseorang untuk menjalankan hidup yang produktif dan dapat menyesuaikan pada tiap pembebanan atau stress fisik yang layak.

\section{Hakikat Kemampuan Menggunakan Media Balok}

Media sebagai salah satu komponen utama pembelajaran. Menurut Moore (2005) media sebagai sesuatu yang berfungsi untuk memudahkan peserta didik memahami materi belajar dan mencapai tujuan belajar. Ini berarti media selain digunakan dan bermanfaat untuk guru juga bermanfaat untuk peserta didik Penggunaan media membutuhkan kemampuan untuk menggunakannya secara maksimal. Kemampuan oleh Gagne (1992) diartikan sebagai suatu daya atau kekuatan yang dimiliki.

Menurut Anggani (2002) terdapat tiga jenis main, yaitu main sensori motor, main peran, dan main pembangunan. Main sensori motor merupakan respon yang paling sederhana hingga gerakan yang lebih terarah dan bermakna. Misalnya, bayi menggeliat karena disentuh, gerakan meregang atau menendang. Main peran ialah kegiatan yang menggunakan kemampuan berfikir yang lebih tinggi karena anak sudah dapat mengendalikan atau menahan pengalaman yang didapat melalui 
panca indra. Main peran sebagai dasar untuk mengembangkan daya cipta, tahapan ingatan, kerja kelompok, dan lain sebagainya. Main pembangunan merupakan kegiatan yang berkaitan dengan fisik dan pengembangan keterampilan yang mendukung tugas - tugas persekolahan.

Anggani (2000) menjelaskan bahwa balok dapat digunakan sebagai alat permainan. Sedangkan menurut Chalufour dan Worth (2004) balok merupakan sesuatu yang digunakan untuk membuat bangunan. Dengan balok anak dapat membuat rumah, mobil atau apa saja dalam bentuk bangunan. Selanjutnya Chalufour menjelaskan bahwa dengan balok anak mulai bereksplorasi, baik sendiri - sendiri maupun berkelompok. Pada umumnya anak melakukan berbagai aktifitas dengan menggunakan balok dalam suasana senang dan gembira.situasi tersebut oleh Chalufour dan Worth dinyatakan sebagai bermain balok.

Berdasarkan uraian di atas dapat dikemukakan bermain balok merupakan suatu aktifitas menggunakan sesuatu benda yang memiliki variasi bentuk, ukuran dan warna untuk menghasilkan bentuk bangunan tertentu. Selanjutnya Anggani menjelaskan bahwa balok terdiri dari empat bentuk, yaitu balok unit, balok berongga, balok berwarna, puzzles. Puzzles terdiri dari puzzle terstruktur dan puzzle bebas.

\section{Penelitian Yang Relevan}

Hasil penelitian yang dilakukan oleh IPB Bogor membandingkan anak Barat dan anak Indonesia yang usia dini ternyata diketahui bahwa perkembangan motorik pada anak indonesia tergolong rendah. Hasil penelitian yang dilakukan oleh CRI (1997) menunjukkan bahwa kegiatan di luar ruangan menjadi penentu perkembangan otot.

Dockett dan Fleer (1999) menyatakan bahwa banyak hal yang mempengaruhi aspek perkembangan motorik kasar, di antaranya fisik anak, ukuran tubuh, kaki, tangan, dan anggota lainnya yang langsung berhubungan dengan gerak anak.

Menurut Karel (2000) olah raga memberi sumbangan yang berarti bagi perkembangan anak. Hevitsky dan Strup pada penelitiannya menemukan bahwa kekurangan gizi menyebabkan functional isolationism 'isolasi diri' yaitu mempertahankan untuk tidak mengeluarkan energi yang banyak dengan mengulangi aktivitas.

\section{Kerangka Berpikir}

Hubungan Kesempatan Bermain dengan Perkembangan Motorik

Setiap anak memiliki kesempatan bermain. Kesempatan bermain sebagai keleluasaan anak melakukan berbagai aktivitas yang menyenangkan di TK dan di rumah. Anak memiliki waktu untuk berjalan, berlari, melompat, jongkok, memanjat, merayap dan merangkak. Anak juga dapat melakukan sesuatu dengan menggunakan pasir, air, 
daun-daun atau segala sesuatu yang ada di sekitarnya.

Keleluasaan anak melakukan berbagai aktivitas memberi pengalaman gerakan baik gerakan anggota tubuh secara keseluruhan mapun gerakan anggota tubuh tertentu seperti gerakan jari-jari. Anak menjadi kokoh berjalan, berlari, melompat, memanjat, melakukan aktivitas dengan menggunakan tali, guru atau yang lainnya. Aktivitas tersebut merupakan rangkaian aktivitas yang menggambarkan perkembangan motorik. Semakin banyak atau luas kesempatan anak bermain semakin banyak variasi dan jenis akivitas gerak yang dapat dilakukan anak.

\section{Hubungan Kebugaran Tubuh dengan Perkembangan Motorik}

Kebugaran tubuh sebagai suatu kondisi fisik yang dilihat dari ukuran tinggi dan berat badang, panjang lengan dan ukuran besar kepala yang seimbang. Kondisi tubuh yang serasi dan seimbang memudahkan anak untuk berjalan, berlari, memanjat atau yang lainnya. Gerakan yang dilakukan anak dari mulai gerakan yang masih kaku sampai anak melakukannya dengan gerakan yang luwes. Bila anak dapat melakukan gerakan tersebut maka perkembangan motorik anak akan terpacu.

Gerakan yang dilakukan anak juga berkaitan dengann daya tahan tubuh yang dimiliki anak. Daya tahan tubuh yang tinggi memberi kesempatan anak untuk melakukan gerakan yang banyak dan bervariasi. Daya tahan tubuh yang kuat membuat gerakan menjadi lebih kuat. Selain itu, gerakan dapat dilakukan dalam waktu yang lebih lama karena anak tidak cepat lelah sehingga terus beraktivitas.

\section{Hubungan Kemampuan Menggunakan Media Balok dengan Perkembangan Motorik}

Kemampuan menggunakan media balok sebagai kesanggupan memakai balok berbagai ukuran, bentuk dan warna untuk menghasilkan suatu bangunan. Anak yang memiliki kesanggupan atau kekuatan akan memakai media balok untuk menyusun balok dengan berbagai bentuk. Anak membuat jembatan, rumah, menara pintu gerbang atau yang lainnya.

Anak yang memiliki kemampuan menggunakan balok akan menggunakan balok dengan jumlah yang lebih banyak. Anak juga dapat menggunakan balok yang bervariasi bentuk, ukuran dan warnanya. Anak dapat menggunakan balok segi empat, bulat, segi tiga atau yang lainnya untuk menghasilkan suatu bentuk atau bangunan. Dengan menggunakan balok bervariasi akan diperoleh hasil yang bervariasi. Misalnya, anak akan dapat menghasilkan menara, jembatan rumah atau yang lainnya akan memicu anak untuk terus memakai balok untuk mencoba menghasilkan yang lainnya. Aktivitas ini akan melenturkan gerakan anak, khsususnya gerakan yang berkaitan 
dengan jari. Kelenturan gerakan tersebut merupakan bagian dari perkembangan motorik anak. Dengan demikian dapat di duga bahwa terdapat hubungan positif kemampuan menggunakan media balok dengan perkembangan motorik.

Hubungan Kesempatan Bermain, Kebugaran Tubuh dan Kemampuan Menggunakan Media Balok Secara Bersama-sama Dengan Perkembangan Motorik

Kesempatan bermain sebagai keleluasaan yang dimiliki anak untuk melakukan berbagai aktivitas yang menyenangkan. Di mana dan kapan saja anak dapat melakukan berbagai aktivitas. Anak berjalan, berlari, melompat, jongkok, memanjat atau yang lainnya. Anak juga dapat melakukan aktivitas melempar, menangkap dan meraih sesuatu sambil berjalan atau melompat.

Aktivitas bermain yang dilakukan anak sebagai suatu gerakan yang dapat membentuk postur tubuh. Lengan dan tungkai akan berkembang menjadi panjang. Gerakan tubuh menjadi lincah, postur tubuh terbentuk dan memiliki gerakan yang lentur dan luwes. Semua itu akan membangun tubuh yang bugar. Dengan tubuh yang bugar gerakan yang dilakukan anak semakin terarah dan stabil. Anak semakin dapat meningkatkan kualitas gerakan seperti, jangkauan lompatan bertambah, semakin kencang berlari, semakin kuat berjalan dan berlari, semakin cepat memanjat dan lainnya.
Anak juga akan lebih terarah menggerakkan jari-jari tangannya untuk menangkap, melempar, membentuk dan lainnya. Kesempatan bermain yang dimiliki anak didukung dengan kebugaran tubuh memberi peluang kepada anak untuk meningkatkan kelenturan gerak dan kordinasi gerak anggota tubuh. Gerakan yang dihasilkan akan mendukung perkembangan motorik.

\section{Hipotesis Penelitian}

Berdasarkan deskripsi teoretis dan kerangka berpikir maka dapat diajukan hipotesis penelitian ini, yaitu

a. Terdapat hubungan positif yang signifikan antara kesempatan bermain dengan perkembangan motorik anak TK di Kota Medan

b. Terdapat hubungan positif yang signifikan antara kebugaran tubuh dengan Perkembangan Motorik Anak TK di Kota Medan

c. Terdapat hubungan positif yang signifikan antara kemampuan menggunakan media balok dengan perkembangan motorik anak TK di Kota Medan

d. Terdapat hubungan positif yang signifikan antara kesempatan bermain, kebugaran tubuh, dan penggunaan media balok secara bersama-sama dengan perkembangan motorik anak TK di Kota Medan. 
METODOLOGI PENELITIAN

\section{Tempat dan Waktu Penelitian}

Penelitian ini dilakukan di TK se Kota Medan. Penelitian dilaksanakan selama 6 bulan yaitu mulai bulan Januari sampai bulan Juni 2010.

\section{Populasi dan Sampel \\ Populasi Penelitian}

Populasi penelitian ini adalah seluruh anak TK kelompok B di Kota Medan. Berdasarkan data yang diperoleh dari Kantor Dinas Pendidikan Kota Medan tahun 2009/2010 diketahui bahwa jumlah TK yang menyebar di 20 kecamatan se Kota Medan sebanyak 330 unit dengan jumlah anak kelompok B sebanyak 12973 orang yang berusia 5 tahun sampai 6 tahun.

Umumnya kelompok anak usia 5 sampai 6 tahun memiliki karakteristik yang sama. Di TK umumnya mereka mengikuti kegiatan belajar yang disusun berdasarkan kurikulum yang sama, yaitu kurikulum TK 2004. Berdasarkan karakteristik tersebut dapat dinyatakan bahwa populasi penelitian ini cenderung homogen.

\section{Metode dan Rancangan Penelitian} Penelitian menggunakan pendekatan kuantitatif dengan metode deskriptif korelasional. Penelitian ini akan memberi gambaran sampai sejauhmana kesempatan bermain, kebugaran tubuh, dan menggunakan media balok dapat memberikan hubungan dengan perkembangan motorik anak, dan variabel mana yang paling kuat hubungannya akan memberikan gambaran sumbangan variabel bebas terhadap perkembangan motorik anak. Studi penelitian ini menggunakan empat variabel. Satu variabel terikat yaitu perkembangan motorik (Y), tiga variabel bebas, yaitu kesempatan bermain (X1), kebugaran tubuh (X2), dan kemampuan menggunakan media balok (X3). Dalam penelitian ini tiga variabel bebas dikorelasikan dengan variabel terikat baik sendiri-sendiri mapun bersama-sama.

\section{Variabel Penelitian}

Variabel penelitian ini ada empat. Satu variabel terikat, yaitu perkembangan motorik (Y). Tiga variabel bebas, yaitu kesempatan bermain (X1), kebugaran tubuh (X2), dan kemampuan menggunakan media balok (X3).

\section{Definisi Operasional}

Definisi Konseptual

Perkembangan motorik merupakan penguasaan gerakan sesuai dengan fungsi setiap anggota gerak tubuh.

\section{Definisi Operasional}

Perkembangan motorik merupakan penguasaan gerakan yang dilakukan anak sesuai dengan fungsi anggota gerak tubuh yang terdiri dari motorik halus dan motorik kasar yang terlihat dalam berbagai aktivitas. Variabel ini diukur dengan menggunakan instrumen tes.

a. Variabel Bebas

Kesempatan Bermain 
Kesempatan bermain merupakan keleluasaan anak menggunakan waktunya untuk melakukan berbagai aktivitas yang menyenangkan. Kesempatan bermain merupakan banyaknya waktu, jumlah dan variasi bermain yang digunakan anak saat melakukan aktivitas yang menyenangkan. Variabel ini diukur dengan menggunakan angket.

Kebugaran Tubuh

Kebugaran tubuh sebagai kondisi fisik yang siap melakukan kegiatan sehari - hari, penuh kesiapsiagaan tanpa lelah untuk mengisi waktu senggangnya. Kebugaran tubuh sebagai kondisi tampilan fisik yang kuat dan siap melakukan aktivitas sehari-hari tanpa lelah. Variabel ini diukur dengan menggunakan dengan daftar isian. Kemampuan Menggunakan Media Balok. Kemampuan menggunakan media balok merupakan kesanggupan memakai sejumlah balok dengan variasi, ukuran, bentuk dan warna untuk menghasilkan suatu bangunan. Kemampuan menggunakan media balok sebagai kecakapan anak memakai sejumlah balok dengan variasi ukuran, bentuk dan warna yang serasi sehingga menghasilkan suatu bangunan. Variabel ini diukur dengan menggunakan daftar isian.

\section{Teknik dan Instrumen}

\section{Pengumpulan Data}

Teknik Pengumpulan Data

Data yang dibutuhkan dalam penelitian dikumpulkan dengan tes, angket dan daftar isian. Tes digunakan untuk mengumpulkan data variabel perkembangan motorik, angket digunakan untuk mengumpulkan data kesempatan bermain, kebugaran tubuh dan kemampuan menggunakan balok dikumpulkan dengan menggunakan daftar isian.

\section{Instrumen Pengumpul Data}

Tes Perkembangan Motorik Anak

Menurut Feeney, Christensen, Moravcik (2004) perkembangan motorik dapat diukur dengan menggunakan instrumen tes. Tes tersebut dikenal sebagai tes informal, berdasarkan indikator perkembangan motorik yang dikemukakan oleh Feeney, maka dapat dikembangkan tes perkembangan motorik sebanyak 34 butir.

Tes perkembangan motorik anak disusun sebanyak 34 butir. Tes yang digunakan berbentuk intruksi yang harus dilakukan anak. Bila anak berhasil memenuhi instruksi tersebut maka anak diberi skor 1 dan apabila belum berhasil diberi skor 0 (nol).

\section{Angket Kesempatan Bermain}

Angket untuk mengukur kesempatan bermain menggunakan 4 skala, yaitu 4 selalu, 3 sering, 2 jarang, 1 tidak pernah. Kisi-kisi kesempatan bermain

\section{Daftar Isian Kebugaran Tubuh}

Daftar isian yang digunakan dalam penelitian ini adalah kebugaran tubuh dan kemampuan menggunakan media balok. Daftar 
isian kebugaran tubuh memiliki skor 3 sesuai, 2 kurang sesuai dan 1 tidak sesuai. Instrumen dikembangkan dengan menggunakan kisi-kisi

\section{Uji Coba Instrumen}

Sebelum dilakukan pengumpulan data penelitian, pada instrumen terlebih dahulu dilakukan uji coba, dengan tujuan untuk menjaring butir pertanyaan yang valid (sahih) serta mendapatkan instrumen penelitian yang reliable, maka uji coba tes, angket, daftar isian dilakukan pada anak TK ABA Busthanul Atfal Bromo Medan yang berjumlah 40 orang dari kelompok B. Untuk tes kemampuan motorik jumlah item disiapkan sebanyak 35 butir, untuk kesempatan bermain jumlah item 15 butir, untuk kebugaran tubuh 10 butir, dan untuk kemampuan menggunakan media balok jumlah item 20 butir. Adapun validitas isi yang digunakan dalam penyusunan angket maupun daftar isian adalah dengan menyesuaikannya pada indikator masing-masing instrumen yang tertuang dalam lampiran 5a, 5b, 5c, dan 5d pada halaman 104 - 110.

\section{Teknik Analisa Data}

Teknik analisa data yang digunakan adalah teknik statistik deskriptif dan inferensial. Teknik deskriptif digunakan untuk mendiskripsikan data setiap variabel penelitian serta digunakan untuk mencari : Skor tertinggi, skor terendah, harga rata-rata (mean), simpangan baku dan kategori masing-masing variabel dilihat dari nilai mean masing-masing variabel. Kemudian disusun daftar distribusi frekuensi yang meliputi frekuensi observatif, frekuensi relatif, dan dibuat histogramnya.

\section{HASIL PENELITIAN DAN PEMBAHASAN \\ Deskripsi Data Penelitian \\ Data Perkembangan Motorik}

Skor ideal berada pada rentang 0 sampai 34 , dengan rata-rata ideal 17. Data perkembangan motorik anak (Y), skor tertinggi 33 dan skor terendah 18. Nilai rata-rata $X=25,35$, standar deviasi $(\mathrm{s})=43,74$, varians $\left(\mathrm{s}^{2}\right)=13,97, \quad$ median $\quad(\mathrm{Me})=25.70$, modus $\quad(\mathrm{Mo})=26.25$. Hasil perhitungan selengkapnya pada Lampiran 12. Bila rata-rata ideal dibanding rata-rata hitung maka diperoleh rata-rata hitung di atas rata-rata ideal, sehingga dinyatakan perkembangan motorik anak TK seKota Medan cenderung baik. Dapat dilihat distribusi frekuensi skor perkembangan motorik anak pada Tabel 7 berikut:

Tabel 7. Daftar Distribusi Frekuensi Skor Perkembangan Motorik Anak

\begin{tabular}{|l|l|l|l|}
\hline $\begin{array}{l}\text { No. } \\
\text { Kelas }\end{array}$ & $\begin{array}{l}\text { Interval } \\
\text { Kelas }\end{array}$ & $\begin{array}{l}\text { Frekue } \\
\text { nsi }\end{array}$ & $\begin{array}{l}\text { Persenta } \\
\text { se }\end{array}$ \\
\hline 1 & $18-19$ & 8 & $8 \%$ \\
\hline 2 & $20-21$ & 9 & $9 \%$ \\
\hline 3 & $22-23$ & 14 & $14 \%$ \\
\hline 4 & $24-25$ & 17 & $17 \%$ \\
\hline 5 & $26-27$ & 20 & $20 \%$ \\
\hline 6 & $28-29$ & 15 & $15 \%$ \\
\hline 7 & $30-31$ & 12 & $12 \%$ \\
\hline 8 & $32-33$ & 5 & $5 \%$ \\
\hline Jumlah & 100 & $100 \%$ \\
\hline
\end{tabular}


Berdasarkan Tabel 7 di atas, dapat dijelaskan data skor perkembangan motorik anak sebanyak $31 \%$ di bawah skor rata-rata, $17 \%$ pada skor rata-rata dan sebanyak $52 \%$ di atas skor rata-rata. Dalam bentuk histogram, distribusi skor perkembangan motorik anak dapat dilihat pada gambar 3 di bawah ini.

\section{Gambar 3. Histogram Perkembangan Motorik Anak}

\section{Data Kebugaran Tubuh}

Skor ideal variabel kebugaran tuguh terendah adalah 9 dan tertinggi 27, dengan rata-rata skor ideal 18. Berdasarkan hasil penelitian yang dilakukan, diperoleh data skor kebugaran tubuh $\left(\mathrm{X}_{2}\right)$ dengan skor tertinggi 27 dan skor terendah 12 . Nilai rata-rata $\overline{\mathrm{X}}=20,20$, standar deviasi $(\mathrm{s})=3.76$, varians $\left(\mathrm{s}^{2}\right)$ $=14,13$, median $(\mathrm{Me})=20.19$, modus $(\mathrm{Mo})=20,09$ dan hasil perhitungan selengkapnya pada Lampiran 5. Bila dilihat rata-rata ideal dengan rata-rata hitung diketahui rata-rata hitung lebih besara darai rata-rata ideal. Berdasarkan data ini dapat dinyatakan anak-anak TK di Kota Medan memiliki kebugaran tubuh cenderung kategori baik. Untuk melihat gambaran lebih jelasnya sebaran data kebugaran tubuh anak dapat dilihat pada distribusi frekuensi skor kesempatan bermain anak pada Tabel 8 berikut:
Tabel 8. Daftar Distribusi Frekuensi Skor Kebugaran Tubuh

\begin{tabular}{|l|l|l|l|}
\hline $\begin{array}{l}\text { No. } \\
\text { Kelas }\end{array}$ & $\begin{array}{l}\text { Interval } \\
\text { Kelas }\end{array}$ & Frekuensi & $\%$ \\
\hline 1 & $12-13$ & 6 & $6 \%$ \\
\hline 2 & $14-15$ & 6 & $6 \%$ \\
\hline 3 & $16-17$ & 11 & $11 \%$ \\
\hline 4 & $18-19$ & 21 & $21 \%$ \\
\hline 5 & $20-21$ & 26 & $26 \%$ \\
\hline 6 & $22-23$ & 14 & $14 \%$ \\
\hline 7 & $24-25$ & 10 & $10 \%$ \\
\hline 8 & $26-27$ & 6 & $6 \%$ \\
\hline \multicolumn{2}{|l}{ Jumlah } & 100 & $100 \%$ \\
\hline
\end{tabular}

Berdasarkan Tabel 8 di atas, dapat dijelaskan data skor kebugaran tubuh sebanyak $44 \%$ di bawah skor rata-rata, $26 \%$ pada skor rata-rata dan sebanyak 30\% di atas skor rata-rata.

\section{Data Kemampuan Menggunakan Media Balok}

Skor ideal variabel kemampuan menggunakan media balok terendah adalah 15 dan tertinggi adalah 45, dengan skor rata-rata ideal 30 . Berdasarkan hasil penelitian yang dilakukan, diperoleh data skor kemampuan menggunakan media balok $\left(\mathrm{X}_{3}\right)$ dengan skor tertinggi 43 dan skor terendah 12 . Nilai rata-rata $\overline{\mathrm{X}}=29,05$, standar deviasi $(\mathrm{s})=8.39$, varians $\quad\left(\mathrm{s}^{2}\right)=70,45, \quad$ median $(\mathrm{Me})=29.19, \quad$ modus $\quad(\mathrm{Mo})=29,28$ sama dan hasil perhitungan selengkapnya pada Lampiran 12. Bila rata-rata ideal dibandingkan dengan rata-rata hitung diketahui bahwa rata-rata hitung hampir besarnya dengan rata-rata ideal. Untuk melihat gambaran lebih jelasnya sebaran data kebugaran 
tubuh anak dapat dilihat pada distribusi frekuensi skor kesempatan bermain anak pada Tabel 9 berikut

Daftar Distribusi Frekuensi Skor Kemampuan Menggunakan Media Balok

\begin{tabular}{|c|c|c|c|}
\hline $\begin{array}{l}\text { No. } \\
\text { Kelas }\end{array}$ & $\begin{array}{l}\text { Interval } \\
\text { Kelas }\end{array}$ & Frekuensi & $\%$ \\
\hline 1 & $12-16$ & 9 & $9 \%$ \\
\hline 2 & $17-21$ & 11 & $11 \%$ \\
\hline 3 & $22-26$ & 16 & $16 \%$ \\
\hline 4 & $27-31$ & 26 & $26 \%$ \\
\hline 5 & $32-36$ & 18 & $18 \%$ \\
\hline 6 & $37-41$ & 12 & $12 \%$ \\
\hline 7 & $42-46$ & 8 & $8 \%$ \\
\hline \multicolumn{2}{|c|}{ Jumlah } & 100 & $100 \%$ \\
\hline
\end{tabular}

Berdasarkan Tabel 9. di atas, dapat dijelaskan data skor kemampuan menggunakan media balok sebanyak $36 \%$ di bawah skor rata-rata, $26 \%$ pada skor rata-rata dan sebanyak $38 \%$ di atas skor rata-rata.

\section{Data Kesempatan Bermain}

Skor ideal kesempatan bermain berada pada rentang 13 sampai 52 dengan rata-rata ideal sebesar 32,5. Berdasarkan hasil penelitian yang dilakukan, diperoleh data skor kesepatan bermain anak $\left(\mathrm{X}_{1}\right)$ dengan skor tertinggi 52 dan skor terendah

13. Nilai rata-rata $(\bar{X})=32,90$, standar deviasi $(\mathrm{s})=9,70$, varians $\left(\mathrm{s}^{2}\right)=94,13$, median $(\mathrm{Me})=32,50$, Modus $(\mathrm{Mo})=31.64$ dan hasil perhitungan selengkapnya dilihat pada lampiran 12. Untuk melihat gambaran lebih jelasnya sebaran data untuk kesempatan bermain anak dapat dilihat pada distribusi frekuensi skor kesempatan bermain anak pada Tabel 10 berikut.

Tabel 10. Daftar Distribusi

Frekuensi Skor Kesempatan Bermain Anak

\begin{tabular}{|l|l|l|l|}
\hline $\begin{array}{l}\text { No. } \\
\text { Kelas }\end{array}$ & $\begin{array}{l}\text { Interval } \\
\text { Kelas }\end{array}$ & Frekuensi & $\%$ \\
\hline 1 & $15-19$ & 10 & $10 \%$ \\
\hline 2 & $20-24$ & 11 & $11 \%$ \\
\hline 3 & $25-29$ & 17 & $17 \%$ \\
\hline 4 & $30-34$ & 20 & $20 \%$ \\
\hline 5 & $35-39$ & 16 & $16 \%$ \\
\hline 6 & $40-44$ & 12 & $12 \%$ \\
\hline 7 & $45-49$ & 9 & $9 \%$ \\
\hline 8 & $50-54$ & 5 & $5 \%$ \\
\hline & Jumlah & 100 & $100 \%$ \\
\hline
\end{tabular}

Berdasarkan Tabel 10. di atas, dapat dijelaskan data skor kesempatan bermain anak sebanyak $38 \%$ di bawah skor rata-rata, $20 \%$ pada skor rata-rata dan sebanyak $42 \%$ di atas skor rata-rata.

\section{Pembahasan Hasil Penelitian} Hubungan Kesempatan Bermain dengan Pekembangan Motorik Anak

Hasil penelitian menunjukkan bahwa terdapat hubungan yang positif antara kesempatan bermain dengan perkembangan motorik anak. Kesempatan bermain memberikan konstribusi $29.0 \quad \%$ terhadap perkembangan motorik anak. Artinya variasi perkembangan motorik anak dapat ditentukan $29 \%$ variasi kesempatan bermain. 
Hubungan Kebugaran Tubuh dengan Pekembangan Motorik Anak

Hasil penelitian menunjukkan bahwa terdapat hubungan yang positif dan berarti antara kebugaran tubuh dengan perkembangan motorik anak. Kebugaran tubuh memberikan konstribusi $47.7 \%$ terhadap perkembangan motorik anak. Artinya variasi perkembangan motorik anak ditentukan oleh $47,7 \%$ variasi kebugaran tubuh anak. Kaufman (2000) menyatakan bahwa penampilan sehat dapat dilihat dari tampilan fisik, yaitu kesesuaian tinggi badan, berat badan, panjang lengan dan lingkar kepala.

\section{Hubungan Kemampuan menggunakan Media Balok dengan Pekembangan Motorik Anak}

Hasil penelitian menunjukkan bahwa terdapat hubungan yang positif dan berarti antara kemampuan menggunakan media balok dengan perkembangan motorik anak. Kemampuan menggunakan media balok memberikan konstribusi 35,3 $\%$ terhadap perkembangan motorik anak. Artinya variasi perkembangan motorik anak ditentukan oleh 35,3\% variasi kemampuan menggunakan media balok anak.
Hubungan Kesempatan Bermain, Kebugaran Tubuh dan Kemampuan menggunakan Media Balok Secara Bersama-sama dengan Pekembangan Motorik Anak

Kesempatan bermain sebagai keleluasaan yang dimiliki anak untuk melakukan berbagai aktivitas yang menyenangkan dengan prinsip di mana dan kapan saja anak dapat melakukan berbagai aktivitas. Anak berjalan, berlari, melompat, jongkok, memanjat, melempar, menangkap dan meraih sesuatu sambil berjalan atau melompat adalah sebagian kecil contoh aktivitas yang dapat dilakukan anak Maxim (1993) menyatakan, bermain merupakan bagian yang sangat penting bagi seluruh kehidupan anak. Selanjutnya Mayke (2001) menyatakan, setiap anak memiliki insting untuk bermain dalam menumbuhkan kreativitasnya untuk pola tertentu dalam membantu proses pertumbuhan dan perkembangannya. Sesuai hasil yang diperoleh dalam penelitian ini didapat anak yang memiliki kesempatan bermain yang cukup, memberikan sumbangan yang berarti terhadap perkembangan motoriknya sendiri, apalagi didukung dengan media yang variatif.

\section{SIMPULAN DAN SARAN}

\section{Simpulan}

Berdasarkan hasil analisis data dan pengujian hipotesis, maka dapat ditarik simpulan seperti diuraikan di bawah ini : 
a. Tingkat kecenderungan perkembangan motorik anak dinyatakan kategori cukup, yaitu sebesar 18 (52,94\%), tingkat kecenderungan kesempatan bermain dinyatakan kategori cukup, yaitu sebesar 25 (48,08\%), tingkat kecenderungan kebugaran tubuh dinyatakan kategori tinggi, yaitu sebesar $6(66,67 \%)$, dan tingkat kecenderungan kesempatan menggunakan media balok dinyatakan kategori cukup, yaitu sebesar 28 (62,22\%).

b. Terdapat hubungan yang positif antara kesempatan bermain dengan perkembangan motorik anak. Hal ini mengindikasikan bahwa semakin sering anak mengikuti permainan, maka perkembangan motorik anak juga akan semakin baik.

c. Terdapat hubungan yang positif antara kebugaran tubuh dengan perkembangan motorik anak. Hal ini mengindikasikan bahwa semakin bugar tubuh seorang anak, maka perkembangan motorik anak juga akan semakin baik.

d. Terdapat hubungan yang positif antara kemampuan menggunakan media balok dengan perkembangan motorik Anak. Hal ini mengindikasikan baha semakin tinggi kemampuan anak dalam menggunakan media balok, maka perkembangan motorik anak juga akan semakin baik. e. Dalam analisis korelasi parsial, jika variabel kebugaran tubuh dan kemampuan menggunakan media balok dikontrol terdapat hubungan yang positif antara kesempatan bermain dengan perkembangan motorik anak. Jika variabel kesempatan bermain dan kemampuan menggunakan media balok dikontrol, terdapat hubungan positif antara kebugaran tubuh dengan perkembangan motorik anak. Selanjutnya jika kesempatan bermain dan kebugaran tubuh dikontrol maka terdapat hubungan yang positif antara kemampuan menggunakan media balok dengan perkembangan motorik anak.

\section{Saran}

a. Bagi orang tua, diharapkan dapat mengenali perkembangan motorik anaknya serta memberikan kesempatan dan upaya untuk mengembangkan motorik anak.

b. Bagi guru, diharapkan dapat menyusun program yang dapat menjadi jembatan kegiatan belajar guna membantu dan merangsang perkembangan motorik anak.

c. Bagi Kepala TK, diharapkan memberi kesempatan dan mendorong guru untuk memaksimal program pengembangan motorik anak dan menyediakan berbagai fasilitas (APE) dengan berupaya menjalin 
kerjasama dengan lembagalembaga atau instansi-instansi yang berkompeten guna meningkatkan pengembangan motorik anak.

d. Bagi Diknas dan lembagalemabaga terkait, diharapkan dapat mendukung program pengembangan motorik anak dengan menyediakan berbagai fasilitas dan sarana prasarana yang mendukung.

e. Bagi LPTK, diharapkan dapat membantu dan memnfasilitasi guru dalam mengembangkan program yang berkaitan dengan pengembangan motorik dan menyiapkan mahasiswa PAUD yang memiliki kompetensi melaksanakan kegiatan pengembangan motorik anak.

\section{DAFTAR RUJUKAN}

Anonim. (1999). Pedoman Pembinaan Kesehatan Anak didik Taman Kanak - kanak. Jakarta: Departemen Kesehatan RI Direktorat Bina Kesehatan .

Anonim.(2005). Instrumen Deteksi Dini Penyimpangan Perkembangan pada Balita dan Anak Prasekolah. Jakarta : Departemen Kesehatan RI.

Arikunto, Suharsimi. (2008). Dasar - Dasar Evaluasi Pendidikan. Jakarta : Bumi Aksara

Boehlke, Robert. R; "Friedrich W.A. Froebel. (1997). Pendiri Taman Kanak-kanak", dalam Sejarah Perkembangan
Pikiran. Jakarta: BPK Gunung Mulia.

Brewer, Jo, Ann. (2007). Introduction to Early Childhood Education Preschool Through Primary Grades sixth edition. New York: Pearson Education, Inc.

Carl Gabbard, Elizabeth LeBlanc, Susan Lowy. (1987). Physical Education for Children Building the foundation. New jersey : A Division of Simon \& Schuster Englewood by Prentice - Hall, Inc.

Chalufour, I. \& Worth, K. (2003). Building structures with young children (the Young Scientist Series). St. Paul, MN: Redleaf Press

Cohen, D.H. (1997). Kindergarten and Early Schooling. London : prentice hall International Incorporation.

Dedi, Supriadi. (2004). Membangun Bangsa Melalui Pendidikan, Editor Rohmat Mulyana. Bandung: PT Remaja Rosdakarya.

Elizabeth B. Hurlock. (1995).

Perkembangan Anak I. Jakarta: Erlangga.

Feeney, Stephanie, Doris Christensen and Eva Moravik.(2006). Who Am I in the lives of Children Seventh Edition. Columbus, Ohio: Pearson Merril Prentice Hall. 
F.J. Monks, A.M.P. Knoers dan Siti Rahayu.(1994). Psikologi Perkembangan, Pengantar dalam Berbagai bagiannya. Yogyakarta: Gajah Mada University.

Gagne, Robert, J. and Leslie J. Briggs.(1992). Principles of Instructional Design. New York: Holt Rinehart and Winston.

Sudono, Anggani. (2002). Sumber Belajar dan Alat Permainan. Jakarta : Grasindo. 